Journal of Social Sciences (COES\&RJ-JSS)

ISSN (E): 2305-9249 ISSN (P): 2305-9494

Publisher: Centre of Excellence for Scientific \& Research Journalism, COES\&RJ LLC

Online Publication Date: $1^{\text {st }}$ January 2015

Online Issue: Volume 4, Number 1, January 2015

http://www.centreofexcellence.net/J/JSS/JSS Mainpage.htm

\title{
An Evaluation of the determinants of Brand equity in fast food business in Hong Kong
}

\begin{abstract}
MAK Yee Mei, Margaret
International Academy of Management, Hong Kong

Abstract:

This study aims to identify and investigate the factors that influence brand equity in the fast food business in Hong Kong. The study will adopt Aaker's Brand Equity Model (1991) to facilitate the understanding on the relationships between the determinants and brand equity, five determinants including (1) brand awareness, (2) brand association, (3) perceived value, (4) perceived quality and (5) brand trust are used for the hypotheses testing.

This study was conducted by using quantitative research methodology (Welman and Kruger, 2011; Creswell, 2003) to collect appropriate data for evaluation and analysis of the findings. Surveys were conducted to collect data from customers directly. Questionnaires were distributed to the customers and a total of 113 valid responses were received from respondents for investigating the key determinants that influencing brand equity.

Through this research, it is expected that we can identify the key determinant of brand attributes that has direct impact on brand equity in the fast food business context. The proposed model can facilitate the marketers to establish an efficient brand building and sustaining mechanism, to implement effective customer-focused marketing strategies and to develop a framework to integrate brand equity with the stakeholders' relationship.
\end{abstract}

\section{Keywords:}

Brand Equity, Brand Awareness, Brand Association, Perceived Value, Perceived Quality, Brand Trust

\section{Citation:}

Mei, MAK Yee; Margaret (2015); An evaluation of the determinants of brand equity in fast food business in Hong Kong; Journal of Social Sciences (COES\&RJ-JSS), Vol.4, No.1, pp: 691-704.

http://dx.doi.org/10.17632/t9s23fgw8y.1 


\section{INTRODUCTION}

The economic environment in running fast food business is becoming very challenging in Hong Kong. The high food cost, shortage of labour supply, highly competitive market and the continued climbing up rental cost are the adverse factors which erode the profit margin of fast food business. In Hong Kong, the market is operating by a lot of diverse market players including premium restaurants in 5-star hotels, casual dining restaurants offering international cuisine and traditional Chinese cuisine, fast food stores, cha-chantang and pop and mom stores etc.

In facing the keen competition of catering business, there are fewer noticeable and tangible differences in the consumer products and service offered among the competitors. Many companies have come to believe that one of their most valuable assets is their brands (Kapferer, 2004; Kotler and Keller, 2006). However, brand might also be the most vulnerable asset as well. Whenever anything goes wrong such as the corrupted top management, unethical working practice, social and environmental damages, the brand reputation will become the victim and be destroyed easily.

Previous researchers have identified many determinants influencing brand equity which included brand awareness (Bogart and Lehman, 1973; Aaker, 1991; Kotler and Keller, 2006), brand association (Aaker, 1991; Yoo, 2000; Kotler and Keller, 2006), perceived value (Patterson \& Spreng, 1997; Luam \& Liu, 2003; Anderson \& Srinivasan, 2003; Armstrong \& Kotler, 2006) and perceived quality (Zeithaml, 1988; Aaker, 1991; Sadler, 1999; Yoo, 2000: Chaudhuri \& Holbrook, 2001).

The purpose of this paper is to identify the key determinants in brand equity based on Aaker's Brand Equity Model (1991) so that companies can develop an effective implementation framework to integrate brand equity in their marketing plans and advertising strategies in order to attain the sustainability and continuous growth of organization.

\section{LITERATURE REVIEW}

There are a lot of studies in dimensions of brand equity. The first and most famous of them presented by Aaker (1991) that brand equity can be measured from the perspective of consumers and includes 5 dimensions : (1) brand awareness, (2) brand association, (3) perceived quality, (4) brand loyalty and (5) other assets associated brand equity related to a company. Many other researchers such as Pappu et al (2006), Gill (2007), Atilgan (2006), Yoo et al (2002) further extended Aaker's Model and expressed 4 dimensions include brand awareness, brand association, brand loyalty and perceived quality for brand equity.

In this research, we extend Aaker's Brand Equity Model (1991) by adding two variables namely : (1) perceived value and (2) brand trust. Through this study, we focus on developing a theoretical model of brand equity showing the relationship between the determinants and brand equity in fast food industry.

\subsection{Brand Equity}

Brand Equity is an instrument to measure the competitive strength of brands (Farguhar, 1989). According to Kotler and Keller (2006), brand equity is the added value endowed to products and services reflected in how customers think, feel, and act with respect to the 
brand, as well as the prices, market share, and profitability that the brand commands for the firm. Brand equity is an important intangible asset that has psychological and financial value to the firm.

Aaker further defines brand equity as a set of brand assets (or liabilities) linked to a brand's name and symbol that add to (or subtract from) a product or service. These assets can be grouped into four dimensions : brand awareness, brand association, perceived quality and brand loyalty.

Brand Equity is the customer's subjective and intangible assessment of the brand, above and beyond its objectively perceived value (Kotler and Keller, 2006; Shwn-lug and ChenLieu, 2009). The subdrivers of brand equity are customer brand awareness, customer attitude toward the brand, and customer perception of brand ethics. Companies use advertising, public relations, and other communication tools will affect these subdrivers.

Therefore, the corporate brand is a valuable intangible asset, that is difficult and imitate, and which may help to achieve sustained superior financial performance (Roberts and Dowling, 2002)

\subsection{Brand Awareness}

Brand awareness has been shown to affect perceptions and even taste. People like the familiar and are prepared to ascribe all sorts of good attitude to items that are familiar to them (Aaker, 1991). Bogart and Lehman (1973) explains that brand awareness came into being from the big consists of dissimilar parts and dependent upon extension to different fields of advertised messages.

According to Kotler and Keller (2006), brand awareness is the consumers' ability to identify the brand in a specific product under different conditions, as reflected by their brand recognition or recall performance. Brand awareness must precede brand associations (Washburn and Plank, 2002) and it is particularly true for new or niche brands by using name, logo, symbol and advertising slogan to facilitate customers in brand recognition and brand recall (Aaker, 1996).

Based on Aaker's (1991) Brand Equity Model, brand awareness is one of the dimensions in assessing the brand equity.

\subsection{Brand Association}

Brand association can be anything that connects the customer to the brand. It can include user imagery, product attributes, use situations, organizational associations, brand personality, and symbols (Aaker, 1991). The more the communication with customers, the stronger is the degree of association.

Brand association is not simply an individual entity but consist of instances, ideas, episodes and facts that are connected to form brand knowledge (Yoo et al., 2000).

According to Kotler and Keller (2006), brand association consists of all brandrelated thoughts, feelings, perceptions, images, experiences, belief, attitudes, and so on, that are linked to the brand. If a product is able to meet consumers' need, consumers will produce psychological association with the brand and raise purchase intention accordingly (Fournier, 1998). Therefore, much of brand management involves determining what 
associations to develop and then creating programs that will link the associations to the brand.

Based on Aaker's (1991) Brand Equity Model, brand association is one of the dimensions in assessing the brand equity.

\subsection{Perceived Value}

Perceived value is made up of several elements : the buyer's image of the product performance, the channel deliverables, warranty quality, customer support, and softer attitudes such as supplier's reputation and trustworthiness (Kotler and Keller, 2006). Each potential customer places different weights on these different elements.

Armstrong \& Kotler (2006) further explains that customer perceived value is the difference between the prospective customer's evaluation of all the benefits and costs of an offering and the perceived alternatives. Total customer value is the perceived monetary value of the bundle of economic, functional, and psychological benefits customers expect from a given market offering. Total customer cost is the bundle of costs that customers expect to incur in evaluating, obtaining, using and disposing of the given market offerings.

Perceived value is important as it relate to customers' satisfaction and the subsequent repeated purchase intention (Patterson \& Spreng, 1997). If the perceived value of customers is low, they may switch their purchase to competing brands (Anderson \& Srinivasan, 2003; Monroe and Krishnan, 1985). Thus, perceived value is a vital catalyst for simulating consumer purchase intention (Thaler, 1985).

\subsection{Perceived Quality}

Perceived quality is defined as "the customers' perception of the overall quality or superiority of a product or service with respect to its intended purpose, relative to alternatives" (Zeithaml, 1988). It is an intangible, overall feeling about a brand (Sadler, 1999).

According to Aaker (1991), perceived quality is a special type of association, partly because it influences brand associations in many contexts and partly because it has been empirically shown to affect profitability. When a high level of perceived quality has been created, it raises not only profit margin but also aids customer perception and create value to the corporation (Aaker, 1991; Yoo et al., 2000).

Perceived quality is one of the dimensions influencing brand equity based on Aaker's Brand Equity Model (1991). Indicators such as brand performance, employee behaviour, product reliability, service quality and physical appearance are measured in this dimension.

\subsection{Brand Trust}

Berry (2000) identifies that brand plays an extraordinary role in companies because brands which are strong will increase the pace of customer's trust of the purchase that is invisible. Trust of the customer and satisfaction with a retailer mediates the impact of trust in brand and satisfaction on customers' intentions to repurchase (Zhoja and Voorhees, 2006). 
Delgado-Ballester \& Munuera-Aleman (2001, 2005) further explain brand trust as the "confident expectations of the brand's reliability and intentions in situations entailing risk to the consumer". They declare that trust association from past experience becomes the part for current purchase and terms the customers as loyal which further intact the brand equity.

Brand trust is important as it relates to customer satisfaction, customer commitment and brand loyalty (Hennig-Thurau et al., 2002; D. Cry et al., 2007). Developing the relationship between customers and brand can help facilitating the connection between company and customers (Sheth and Parvatiyar, 1995). Therefore, brand trust is a vital and necessary construct in developing customer relationship stronger and achieve sustainable share in the market (Sirdeshmukh et al., 2002)

\section{RESEARCH METHODOLOGY}

\subsection{Conceptual Research Framework}

The aim of this study is to identify and investigate the factors that influence brand equity in the fast food business in Hong Kong by adopting and extending Aaker's Brand Equity Model (1991). The variables are identified from various marketing theories developed by famous authors including Aaker (1991), Keller (1993), Woodruff (1997), Yoo et al (2000), Baldauf et al (2003) and Kotler (2006).

A conceptual research framework is constructed as shown in Figure 1 to test the relationship of the various independent variables of brand attributes : brand awareness, brand association, perceived value, perceived quality and brand trust with the dependent variable of brand equity. The questionnaire design, statistical sampling, validating exercise and data analysis model will be developed based on this research framework.

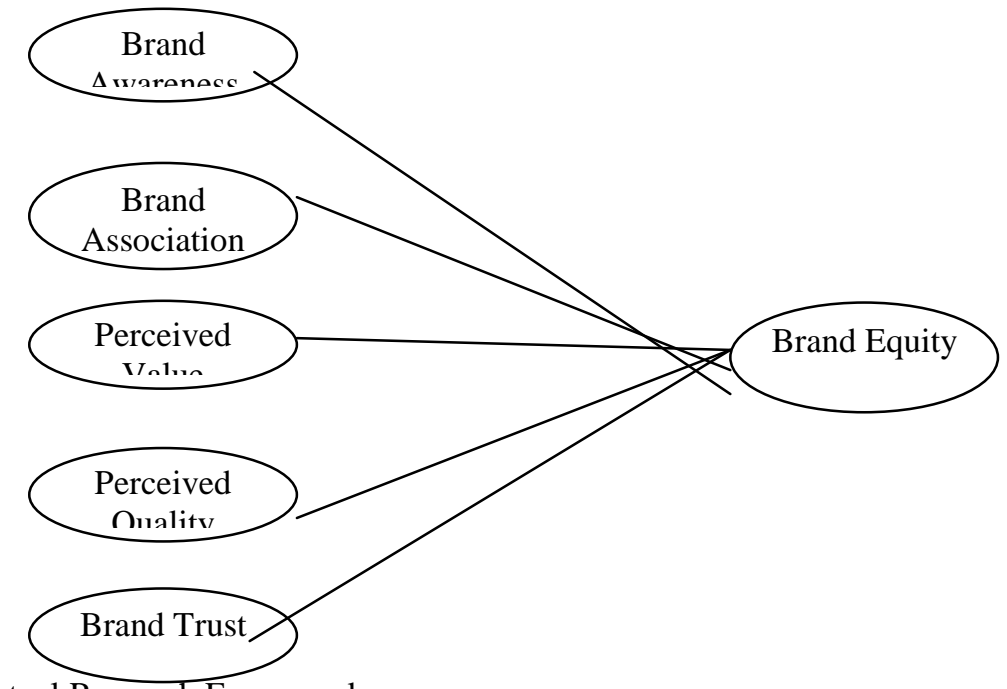

Figure 1 : Conceptual Research Framework 


\subsection{Proposed Hypotheses and Questionnaire Design}

The study was conducted by using both qualitative and quantitative research methodology (Welman and Kruger, 2011; Creswell, 2003) to collect appropriate data for the purpose of identifying the key determinants of brand equity in the fast food business in Hong Kong.

The following hypotheses are proposed and tested with reference to the key objective of this research :

$\mathrm{H} 1$ : Brand awareness is positive related to brand equity

$\mathrm{H} 2$ : Brand association is positive related to brand equity

$\mathrm{H} 3$ : Perceived value is positive related to brand equity

$\mathrm{H} 4$ : Perceived quality is positive related to brand equity

$\mathrm{H} 5$ : Brand trust is positive related to brand equity

In order to investigate those hypotheses, Fairwood Fast Food Limited (Fairwood), a local famous fast food company was selected in this study. Fairwood has been established in Hong Kong for more than 40 years and focuses mainly on the local and PRC fast food markets. Its scale and market share is relatively small when compared with other QuickService-Restaurants (QSR) like McDonald's and KFC.

The target population in this study was customers of Fairwood fast food stores in Hong Kong. Random sampling approach was adopted for data collection. A structured questionnaire with three sections containing 27 questions was prepared (Appendix 1). Section one included branching questions to collect demographics data. Section two aimed at gathering information on various brand attributes including brand awareness $(\mathrm{BW})$, brand association (BA), perceived value (PV), perceived quality (PQ) and brand trust (BT) relating to brand equity for the hypotheses testing. Section three were the personal data of respondents. The research adopted a 5-point Likert scales ranging from $<1>$ strongly disagree to $<5>$ strongly agree.

\subsection{Statistical Sampling}

There were 120 questionnaires distributed and 115 copies were returned. A total of 113 copies were valid after excluding 2 invalid ones with missing data.

In the final sample of 113 respondents as shown in Table 1, $28(24.8 \%)$ of them are male whereas $85(75.2 \%)$ are female. Table 2 shows that there are $49(43.3 \%)$ respondents with age below 30, $53(46.9 \%)$ respondents aged within $31-50$ and $11(9.8 \%)$ of them are over 50. In term of education level as indicated in Table 3, 47 (41.6\%) respondents are graduates from post -secondary colleges or below, 37 (32.7\%) are undergraduates and the other $29(25.7 \%)$ are post-graduates. Among all the respondents, Table 4 indicates that 12 $(10.6 \%)$ are students, $15(13.3 \%)$ work in business-related sectors, $12(10.6 \%)$ are professionals, $60(53.1 \%)$ are workers and the remaining $14(12.4 \%)$ are mainly housewives and retired persons. In view of income distribution in Table 5, 75 (66.3\%) respondents with income below HK\$10,000, 22 (19.5\%) of them are within HK\$10,001 to HK $\$ 20,000$ whereas the rest of $16(14.2 \%)$ respondents with income over HK\$20,000. 


\subsection{Measurement of Descriptive Statistics}

The study variables were analyzed using descriptive statistical methods such as frequency, mean, standard deviation, Cronbach's Alpha and Pearson Correlation. Statistical Package for the Social Sciences (SPSS) software was employed for statistical analysis.

Table 6 depicts the mean and standard deviation of the brand equity under the various brand attributes. The means of all attributes are over 3 and two of them are over 4 which indicate that the respondents ' impression on Fairwood is positive. Brand awareness with respondents' recognizing Fairwood among all types of fast food stores shows a mean of 4.2. It explains that consumers are aware of Fairwood as a long-established famous local brand.

\subsection{Data Analysis and Research Implication}

The internal consistency of the constructs and the reliability of questionnaire are measured by Cronbach's Alpha. The Cronbach's Alpha coefficient for the six constructs including brand awareness (BW), brand association (BA), perceived value (PV), perceived quality $(\mathrm{PQ})$, brand trust (BT) and brand equity (BE) are shown in Table 7. There are 3 questionnaire items for each of the constructs and the results show that all Cronbach's Alpha coefficients are higher than 0.7 except brand awareness (BW) which is slightly below 0.7 at 0.691 . It can be concluded that the data retrieved through the questionnaire is reliable.

Pearson correlation coefficient, symbolized by r, was developed by the English Statistician Karl Pearson (1857 - 1936). It is used to measured the relationship between two variables. The computed value of the correlation coefficient can range from -1.0 to 1.0 , inclusive. The sign of the coefficient indicates the direction of the relationship; the absolute value of the coefficient indicates the magnitude of the relationship.

Pearson correlation is adopted in this study to test if there is relationship existed between the five independent variables of brand attributes on brand equity and the magnitude of such relationship. According to this study, all the brand attributes have positive relationship with brand equity which is validated by the positive sign of all Pearson correlation coefficient as indicated in Table 8. However, the positive correlation of the independent variables of brand association, perceived value, perceived quality and brand trust with the dependent variable brand equity is moderate only. Their r-values ranged between 0.570 to 0.686 . The differences in magnitude of perceived value and brand trust with brand equity is insignificant which implies that these two attributes have an equal influence on brand equity. It is also observed that the relationship between brand awareness and brand equity is very weak with the lowest $r$-value 0.235 whereas that between brand trust and brand equity is stronger as the r-value is the highest at 0.686. In the long run, brand trust is a more critical factor to build up brand equity.

\section{CONCLUSION}

Through this study, the major determinants of brand equity have been identified in the fast food business in Hong Kong. The results of the statistical analysis support all the hypotheses and indicate that the five determinants or attributes that are tested are positively related to brand equity. 
Both perceived value and brand trust show a relatively higher influence on brand equity. This implies that if the customers feel that the perceived value is high, the benefit they get outweigh the cost they pay (Armstrong \& Kotler; 2006), they are willing to spend more and intend to repeat their purchase (Patterson \& Spreng; 1997). Similarly, if the customers have more trust on the products offered and service delivered, it will enhance their satisfaction, commitment and brand loyalty of the company (Hennig-Thurau et al.; 2002; D. Cry et al., 2007). According to Aaker (1991), brand loyalty can be considered as both a dimension and an outcome of brand equity.

The research results also show that brand awareness has a weak influence on brand equity. This explains that a higher brand equity might not be the outcome of a higher awareness of the company's logo, design, brand, products and any other characteristics.

Facing the keen competition and challenging economic environment, the profit margin will easily be eroded. Brand equity becomes one of the key competitive advantages that create tangible value for the sustainability and continuous growth of the company. The results of this research can facilitate the marketers or practitioners to implement effective customer-focused marketing strategies and develop framework to integrate brand equity with the stakeholders' relationship.

The research model can be extended to test the other determinants such as customer satisfaction, brand image, brand loyalty on brand equity and the impact of brand equity on purchase decisions. Though this research was only conducted in the fast food business in Hong Kong, a future extension of the study could be applied and validated the research model in the other industries in Hong Kong or even outside Hong Kong.

\section{REFERENCES}

Aaker, D. A. (1991), Managing Brand Equity: Capitalizing on the Value of a Brand Name, NY: The Free Press (1996), Building Strong Brands, NY: The Free Press.

Aaker, D. A. (1992). The value of brand equity. Journal of business strategy,13(4), 27-32.

Aaker, D.A. (1996). "Brand Extensions : The good, the brand and the ugly", Sloan Management Review, Summer, 47-56.

Aaker, D. A. (1996). Measuring brand equity across products and markets. California management review, 38(3).

Aaker J.L. (1997). Dimension of Brand Personality. Journal of Marketing Research, 34 (August), 347-356.

Aaker J.L. (1999). Brand Personality : A Path to Differentiation in Brands Face the Future, ed. Rory Morgan, New York : Research International, 13-21.

Aaker, D., \& Jacobson, R. (2001). The value relevance of brand attitude in high-technology markets. Journal of Marketing Research, 38(4), 485-493.

Agarwal, M.K. \& Rao, V.R. (1996). An empirical comparison of consumer-based measures of brand equity. Marketing Letters, 7(3), 237-247.

Anderson, E. W., Fornell, C., \& Lehmann, D. R. (1994). Customer satisfaction, market share, and profitability: findings from Sweden. The Journal of Marketing, 53-66.

Armstrong, G \& Kotler, P (2006) Marketing: An Introduction (6th Edition). Prentice Hall, 2006

Atilgan, E., Aksoy, S., \& Akinci, S. (2005). Determinants of the brand equity: a verification approach in the beverage industry in Turkey. Marketing intelligence \& planning, 23(3), 237-248.

Atilgan, E., Aksoy, S., Akinci, S., \& Kaynak, E. (2009). Customer-based brand equity for global 
brands : A multinational approach. Journal of Euromarketing, 18, 115-132.

Baldauf, A., Karen S., \& Gudrun, B. (2003). Performance consequences of brand equity management : Evidence from organizations in the value chain. The Journal of Product and Brand Management, 12(4), 220-236.

Batra R., D.R. Lehmann \& D. Singh (1993). The Brand Personality Component of Brand Goodwill : Some Antecedents and Consequences in Brand Equity and Advertising, David A. Aaker and Alexander Biel, eds. Hillsdale, NJ : Lawrence Erlbaum Associates.

Berry, L.L. (2000). Cultivating service brand equity. Journal of Academy Marketing Sci., 28(1) : $128-137$.

Binninger, A. (2008). Exploring the relationships between retail brands and consumer store loyalty. International Journal of Retail Distribution Management, 36(2) : 94-110.

Bogart, L. and C. Lehman, (1973). What makes a brand name familiar? Journal of Marketing Res., 10(1): 17-22.

Chattopadhyay, A. and Alba, J.W. (1988). The situational importance of recall and inference in consumer decision making'. Journal of Consumer Research, June, Vol. 15, pp. 1-12.

Chaudhuri, A., \& Holbrook, M. B. (2001). The chain of effects from brand trust and brand affect to brand performance: the role of brand loyalty. Journal of marketing, 65(2), 81-93.

Cyr, D., Hassanein, K., Head, M., \& Ivanov, A. (2007). The role of social presence in establishing loyalty in e-Service environments. Interacting with Computers, 19(1), 43-56.

Delgado-Ballester, E., \& Munuera-Aleman, J. L. (2001). Brand trust in the context of consumer loyalty. European Journal of marketing, 35(11/12), 1238-1258.

Delgado-Ballester, E., \& Munuera-Alemán, J. L. (2005). Does brand trust matter to brand equity?. Journal of Product \& Brand Management, 14(3), 187-196.

Esch, Rudolf, F., Langner, T., Echmittm, B. H \& Geus, P. (2006). "Are brands forever? How brand knowledge and relationship affect current and future purchases", Journal of Product and Brand Management, Vol 15, No. 25, 98-105.

Farquhar, P. H. (1989). Managing brand equity. Marketing research, 1(3).

Geuens, Maggie; Weijters, Bert; De Wulf, Kristof "A new measure of brand personality" International Journal of Research in Marketing, 26(2009), 97-107.

Fournier, S. (1994). Consumers and Their Brands : Developing Relationship Theory in Consumer Research. Journal of Consumer Research, 24, 343-373.

Hennig-Thurau, T., Gwinner, K. P., \& Gremler, D. D. (2002). Understanding relationship marketing outcomes an integration of relational benefits and relationship quality. Journal of service research, 4(3), 230-247.

Hooley, Graham J. (2008). Marketing strategy and competitive positioning / Graham J. Hooley, Nigel F. Piercy, Brigitte Nicolaud, $4^{\text {th }}$ ed., New York : FT Prentice Hall.

Keller, K.L. (1993). Conceptualizing, measuring, and managing customer-based brand equity. Journal of Marketing; 57(January): 1-22.

Keller, K. L. (2003). Strategic Brand Management: Building, Measuring and Managing Brand Equity, 2nd ed., Prentice-Hall, Englewood Cliffs, NJ.

Keller, K. L., \& Lehmann, D. R. (2003). How do brands create value? Marketing Management, 12(3), 26-32.

Keller, K. L., \& Lehmann, D. R. (2006). Brands and branding: Research findings and future priorities. Marketing Science, 25(6), 740-759.

Kim, H., \& Kim W. G. (2004a). The relationship between brand equity and firm's performance in luxury hotels and chain restaurants, Tourism Management, 26, 549-560.

Kotler, P. (2006). Introduction of branding. In T. Calkins \& A.M. Tybout (eds), Kelloggon branding (p.ix). Hoboken, NJ : Wiley.

Kolter, P and Keller, L., Marketing Management, $12^{\text {th }}$ ed., Upper Saddler River, NJ. : Prentice Hall 
: 2006.

Krishnan, B. C., \& Hartline, M. D. (2001). Brand equity: is it more important in services?. Journal of Services Marketing, 15(5), 328-342.

Lai, Albert Wenben (1995). "Consumer Values, Product Benefits and Customer Value : A Consumption Behavior Approach", Advances in Consumer Research, Volume 22, No.1, 381-388.

Lassar, W., Mittal, B., \& Sharma, A. (1995). Measuring customer-based brand equity. Journal of consumer marketing, 12(4), 11-19.

Levy S.J. (1959). Symbols for Sales. Harvard Business Review, 37(4), 117-24.

Mackay, M.M. (2001b). Application of brand equity measures in service markets. The Journal of Service Marketing, 15(3), 210-221.

Monroe, K.B. \& Krishnan, R. (1985). The effect of price on subjective product evaluations, perceived quality : How consumers view stores and merchandise, 209-232. In J. Jacoby, \& J. Olson (Ed.), Lexington, MA : D.C. Heath.

Pappu, Ravi (2006). "Consumer-based brand equity and country-of-orgin Relationships". European Journal of Marketing, Emerald Group Publishing Limited, Vol. 40, No. 5/6, 696-717.

Patterson, P. G., \& Spreng, R. A. (1997). Modelling the relationship between perceived value, satisfaction and repurchase intentions in a business-to-business, services context: an empirical examination. International Journal of service Industry management, 8(5), 414434.

Plummer J.T. (1985). Brand Personality : A Strategic Concept For Multinational Advertising in Marketing Educators' Conference. New York : Young \& Rubicam, 1-31.

Porter, M.E. (1974). Consumer behavior, retailer power and market performance in consumer goods industries, Rev. Econ. Stat., 56(4) : 419-436.

Porter, M. E. (1980). Competitive Strategy: Techniques for Analyzing Industries and Competitors. New York: Free Press, 1980.

Roberts, P.W. And G.R. Dowling, (2002). Corporate reputation and sustained superior financial performance. Strategic Management Journal, 23 : 1077-1093.

Shank M.K. \& L. Langmeyer (1994). Does Personality Influence Brand Image?. The Journal of Psychology, 128(2), 157-164.

Sheth, J.N. and Parvatiyar, A. (1995). Relationship marketing in consumer markets: antecedents and consequences. Journal of the Academy of Marketing Science, Vol. 23 No. 4, pp. 25571.

Shwu-Lng, W. and L. Chen-Lien, (2009). The influence of core brand attitude and core-brand perception on purchase intention towards extended product. Journal of Marketing and Logistics, 21(1) : 174-194.

Sirdeshmukh, D., S. Jagdip and S. Barry, (2002). Consumer trust, value and loyalty in relational exchanges. Journal of Marketing, 66(1) : 15-37.

Taylor, S.A. (2004). The importance of brand equity to customer loyalty. The Journal of Product and Brand Management, 13(4), 217-227.

Washburn, J. H., \& Plank, R. E. (2002). Measuring brand equity: an evaluation of a consumerbased brand equity scale. Journal of Marketing Theory and Practice, 10(1).

Westbrook, R. A., \& Reilly, M. D. (1983). Value-percept disparity: an alternative to the disconfirmation of expectations theory of consumer satisfaction. Advances in consumer research, 10(1).

Wong, Y.H. \& B. Merrilees, (1998). Multiple roles for branding in international marketing. Multiple Roles Branding, 3(1-2) : 384-401.

Woodruff, R. B. (1997). Customer value: the next source for competitive advantage. Journal of the academy of marketing science, 25(2), 139-153. 
Yoo, Boonghee, Donthu, N. (2002). "Testing cross-cultural invariance of the brand equity creation process". Journal of Product \& Brand Management, Vol, No. 6, 380-398.

Yoo, Boonghee., Donthu, N., \& Lee, S. (2000). An examination of selected marketing mix elements and brand equity. Journal of the Academy of Marketing Science, 28(2), 195-211.

Zboja, J.J. \& C.M. Voorhees, (2006). The impact of brand trust and satisfaction on retailer repurchase intentions. Journal of Service Maketing, 20(5) : 381-390.

Zeithaml, V. A. (1988). Consumer perceptions of price, quality, and value: a means-end model and synthesis of evidence. Journal of Marketing, 2-22.

Zeithaml, V. A., Berry, L., \& Parasuraman A. (1996). The behavior consequences of service quality. Journal of Marketing, 60(2), 31-46.

\section{TABLES}

Table $1:$ The demographic profile of respondents

\begin{tabular}{|rl|r|r|r|r|}
\hline & Frequency & Percent & Valid Percent & Cumulative Percent \\
\hline Gender & Male & 28 & 24.8 & 24.8 & 24.8 \\
& Female & 85 & 75.2 & 75.2 & 100.0 \\
& Total & 113 & 100.0 & 100.0 & \\
\hline
\end{tabular}

Table 2 : The statistical distribution of age group of respondents

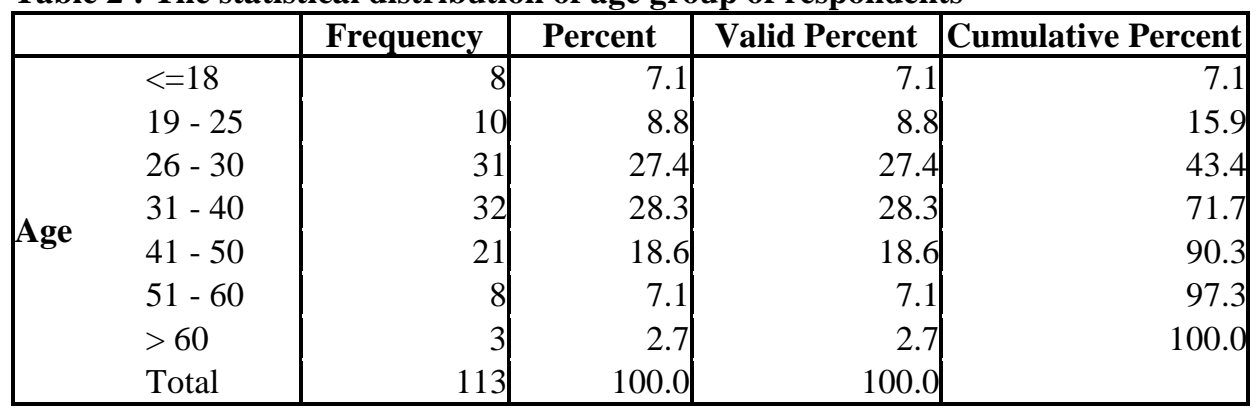

Table 3 : The statistical distribution of education distribution of respondents

\begin{tabular}{|c|r|r|r|r|}
\hline & Frequency & Percent & Valid Percent & \multicolumn{1}{c|}{$\begin{array}{c}\text { Cumulative } \\
\text { Percent }\end{array}$} \\
\hline Primary & $\underline{3}$ & $\underline{2.7}$ & $\underline{2.7}$ & $\underline{2.7}$ \\
\hline Secondary & $\underline{27}$ & $\underline{23.9}$ & $\underline{23.9}$ & $\underline{6.5}$ \\
\hline Post-Secondary & 17 & 15.0 & 15.0 & 41.6 \\
Education & 37 & 32.7 & 32.7 & 74.3 \\
Undergraduate & 29 & 25.7 & 25.7 & 100.0 \\
Postgraduate & 113 & 100.0 & 100.0 & \\
Total & &
\end{tabular}

Table 4 : The statistical distribution of occupation distribution of respondents

\begin{tabular}{|ll|r|r|r|r|}
\hline & & Frequency & Percent & Valid Percent & \multicolumn{2}{c|}{$\begin{array}{c}\text { Cumulative } \\
\text { Percent }\end{array}$} \\
\hline \multirow{2}{*}{ Occupatio } & & & & 10.6 \\
$\mathbf{n}$ & 12 & 10.6 & 10.6 & 22.1 \\
& Student & 13 & 11.5 & 11.5 & 23.0 \\
\hline
\end{tabular}


Journal of Social Sciences (COES\&RJ-JSS), 4(1), pp. 691-704

\begin{tabular}{|l|r|r|r|r|}
\hline Professional & 12 & 10.6 & 10.6 & 33.6 \\
Businessman & 1 & .9 & .9 & 34.5 \\
Housewife & 4 & 3.5 & 3.5 & 38.1 \\
Retired & 2 & 1.8 & 1.8 & 39.8 \\
Front-line & 2.7 & 2.7 & 42.5 \\
Worker & 6 & 53.1 & 53.1 & 95.6 \\
Other & 5 & 4.4 & 4.4 & 100.0 \\
Total & 113 & 100.0 & 100.0 & \\
\hline
\end{tabular}

Table 5 : The statistical distribution of income distribution of respondents

\begin{tabular}{|c|r|r|r|r|}
\hline & Frequency & Percent & Valid Percent & $\begin{array}{c}\text { Cumulative } \\
\text { Percent }\end{array}$ \\
\hline$<=\$ 5,000$ & 70 & 61.9 & 61.9 & 61.9 \\
$\$ 5,000-\$ 10,000$ & 5 & 4.4 & 4.4 & 66.4 \\
$\$ 10,001-\$ 20,000$ & 22 & 19.5 & 19.5 & 85.8 \\
Income $\$ 20,001-\$ 30,000$ & 13 & 11.5 & 11.5 & 97.3 \\
$\$ 40,001-\$ 50,000$ & 1 & .9 & .9 & 98.2 \\
$>\$ 50,000$ & 2 & 1.8 & 1.8 & 100.0 \\
Total & 113 & 100.0 & 100.0 & \\
\hline
\end{tabular}

Table 6 : The descriptive statistics on mean ranking and standard deviation

\begin{tabular}{|l|r|r|}
\hline & \multicolumn{1}{|c|}{ Mean } & \multicolumn{1}{|c|}{$\begin{array}{c}\text { Standard } \\
\text { Deviation }\end{array}$} \\
\hline Brand Awareness (BW) & & \\
\hline - Brand recognition & 4.20 & 0.908 \\
\hline - Logo & 4.19 & 0.962 \\
\hline - Signature products & 3.65 & 1.024 \\
\hline Brand Association (BA) & 3.49 & 0.825 \\
\hline - Various characteristics & 3.29 & 0.932 \\
\hline - Value-for-money products & 3.51 & 0.757 \\
\hline - Positive Impression & & \\
\hline Perceived Value (PV) & 3.23 & 0.886 \\
\hline - Benefit outweigh cost & 3.30 & 0.865 \\
\hline - Value exceeds expectation & 3.45 & 0.886 \\
\hline - Sustainable value & & \\
\hline Perceived Quality (PQ) & & \\
\hline
\end{tabular}




\begin{tabular}{|c|c|c|}
\hline - High food quality & 3.38 & 0.880 \\
\hline - Reliable food safety standard & 3.66 & 0.797 \\
\hline - Professional service quality & 3.66 & 0.809 \\
\hline \multicolumn{3}{|l|}{ Brand Trust (BT) } \\
\hline - Trust in food safety standard & 3.72 & 0.713 \\
\hline - Food quality and service standard meets expectation & 3.62 & 0.783 \\
\hline - Best choice for dining & 3.34 & 1.014 \\
\hline \multicolumn{3}{|l|}{ Brand Equity (BE) } \\
\hline $\begin{array}{l}\text { - I still prefer Fairwood though there are other fast food } \\
\text { stores offering similar menu }\end{array}$ & 3.22 & 0.894 \\
\hline - I consider Fairwood is the most preferable fast food brand & 3.13 & 1.039 \\
\hline - Among all the fast food brands, I still prefer Fairwood & 3.05 & 1.034 \\
\hline
\end{tabular}

Table 7 : Reliability Statistics - Cronbach's Alpha for the Constructs

\begin{tabular}{|l|c|c|}
\hline Constructs & $\begin{array}{c}\text { No. of } \\
\text { Items }\end{array}$ & Cronbach's Alpha \\
\hline Brand Awareness (BW) & 3 & 0.691 \\
\hline Brand Association (BA) & 3 & 0.780 \\
\hline Perceived Value (PV) & 3 & 0.821 \\
\hline Perceived Quality (PQ) & 3 & 0.777 \\
\hline Brand Trust (BT) & 3 & 0.755 \\
\hline Brand Equity (BE) & 3 & 0.897 \\
\hline
\end{tabular}

Table 8 : Test of Hypotheses - Pearson Correlation

\begin{tabular}{|c|c|c|c|c|}
\hline $\begin{array}{c}\text { Hypoth } \\
\text { eses }\end{array}$ & Path & $\begin{array}{c}\text { Pearson } \\
\text { Correlation } \\
\text { r-value }\end{array}$ & $\begin{array}{c}\text { Compu } \\
\text { ted } \\
\text { p-value }\end{array}$ & $\begin{array}{c}\text { Results of } \\
\text { Hypotheses } \\
\text { Test }\end{array}$ \\
\hline
\end{tabular}




\begin{tabular}{|c|l|c|c|c|} 
H1 & $\begin{array}{l}\text { Brand Awareness is positively related to } \\
\text { Brand Equity }\end{array}$ & 0.235 & 0.012 & Support \\
\hline H2 & $\begin{array}{l}\text { Brand Association is positively related to } \\
\text { Brand Equity }\end{array}$ & 0.570 & 0.000 & Support \\
\hline H3 & $\begin{array}{l}\text { Perceived Value is positively related to } \\
\text { Brand Equity }\end{array}$ & 0.676 & 0.000 & Support \\
\hline H4 & $\begin{array}{l}\text { Perceived Quality is positively related to } \\
\text { Brand Equity }\end{array}$ & 0.635 & 0.000 & Support \\
\hline H5 & $\begin{array}{l}\text { Brand Trust is positively related to Brand } \\
\text { Equity }\end{array}$ & 0.686 & 0.000 & Support \\
\hline
\end{tabular}

** Correlation is significant at the 0.01 level (2-tailed)

* Correlation is significant at the 0.05 level (2-tailed)

Table 9 : Pearson Correlation

\begin{tabular}{|c|c|c|c|c|c|c|c|}
\hline & & BW & BA & PA & PQ & BT & $\mathrm{BE}$ \\
\hline BW & $\begin{array}{l}\text { Pearson } \\
\text { Correlation } \\
\text { Sig. (2-tailed) } \\
\text { N }\end{array}$ & $\begin{array}{r}1.000 \\
113.000\end{array}$ & $\begin{array}{r}.420^{* *} \\
.000 \\
113 \\
\end{array}$ & $\begin{array}{r}.355^{* * *} \\
.000 \\
113 \\
\end{array}$ & $\begin{array}{r}.335^{* * *} \\
.000 \\
113 \\
\end{array}$ & $\begin{array}{r}.360^{* *} \\
.000 \\
113 \\
\end{array}$ & $\begin{array}{r}.235^{*} \\
.012 \\
113 \\
\end{array}$ \\
\hline $\mathrm{BA}$ & $\begin{array}{l}\text { Pearson } \\
\text { Correlation } \\
\text { Sig. (2-tailed) } \\
\mathrm{N}\end{array}$ & $\begin{array}{r}.420^{* *} \\
.000 \\
113 \\
\end{array}$ & $\begin{array}{r}1.000 \\
113.000 \\
\end{array}$ & $\begin{array}{r}.680^{* *} \\
.000 \\
113 \\
\end{array}$ & $\begin{array}{r}.482^{* *} \\
.000 \\
113 \\
\end{array}$ & $\begin{array}{r}.557^{* *} \\
.000 \\
113 \\
\end{array}$ & $\begin{array}{r}.570^{* * *} \\
.000 \\
113 \\
\end{array}$ \\
\hline $\mathrm{PA}$ & $\begin{array}{l}\text { Pearson } \\
\text { Correlation } \\
\text { Sig. (2-tailed) } \\
\mathrm{N} \\
\end{array}$ & $\begin{array}{r}.355^{* *} \\
.000 \\
113 \\
\end{array}$ & $\begin{array}{r}.680^{* *} \\
.000 \\
113 \\
\end{array}$ & $\begin{array}{r}1.000 \\
113.000 \\
\end{array}$ & $\begin{array}{r}.611^{* *} \\
.000 \\
113 \\
\end{array}$ & $\begin{array}{r}.641^{* * *} \\
.000 \\
113 \\
\end{array}$ & $\begin{array}{r}.676^{* * *} \\
.000 \\
113 \\
\end{array}$ \\
\hline PQ & $\begin{array}{l}\text { Pearson } \\
\text { Correlation } \\
\text { Sig. (2-tailed) } \\
\mathrm{N}\end{array}$ & $\begin{array}{r}.335^{* *} \\
.000 \\
113 \\
\end{array}$ & $\begin{array}{r}.482^{* *} \\
.000 \\
113 \\
\end{array}$ & $\begin{array}{r}.611^{* *} \\
.000 \\
113 \\
\end{array}$ & $\begin{array}{r}1.000 \\
113.000 \\
\end{array}$ & $\begin{array}{r}.701^{* *} \\
.000 \\
113 \\
\end{array}$ & $\begin{array}{r}.635^{*} \\
.000 \\
113 \\
\end{array}$ \\
\hline BT & $\begin{array}{l}\text { Pearson } \\
\text { Correlation } \\
\text { Sig. (2-tailed) } \\
\mathrm{N}\end{array}$ & $\begin{array}{r}.360^{* *} \\
.000 \\
113 \\
\end{array}$ & $\begin{array}{r}.557^{* *} \\
.000 \\
113 \\
\end{array}$ & $\begin{array}{r}.641^{* *} \\
.000 \\
113 \\
\end{array}$ & $\begin{array}{r}.701^{* * *} \\
.000 \\
113 \\
\end{array}$ & $\begin{array}{r}1.000 \\
113.000 \\
\end{array}$ & $\begin{array}{r}.686^{*} \\
.000 \\
113 \\
\end{array}$ \\
\hline $\mathrm{BE}$ & $\begin{array}{l}\text { Pearson } \\
\text { Correlation } \\
\text { Sig. (2-tailed) } \\
\mathrm{N}\end{array}$ & $\begin{array}{r}.235^{*} \\
.012 \\
113 \\
\end{array}$ & $\begin{array}{r}.570^{* *} \\
.000 \\
113 \\
\end{array}$ & $\begin{array}{r}.676^{* * *} \\
.000 \\
113 \\
\end{array}$ & $\begin{array}{r}.635^{* *} \\
.000 \\
113 \\
\end{array}$ & $\begin{array}{r}.686^{* *} \\
.000 \\
113 \\
\end{array}$ & 113.00 \\
\hline
\end{tabular}

**. Correlation is significant at the 0.01 level (2-tailed).

*. Correlation is significant at the 0.05 level (2-tailed). 